Iwona Kowalczyk

Uniwersytet Łódzki

\title{
ZIELONE ZAMÓWIENIA PUBLICZNE, CZYLI POLITYKA KREOWANIA RYNKU ZGODNEGO Z ZASADAMI ZRÓWNOWAŻONEGO ROZWOJU
}

\section{Wprowadzenie}

Zamówienia publiczne stanowiące, $\mathrm{z}$ uwagi na ich skalę, istotny element systemu prawa i gospodarki wydatkowania środków publicznych, ${ }^{1}$ mogą stać się również świadomym i realnym instrumentem kreowania tejże gospodarki. Każdego roku podmioty publiczne w Polsce wydają kilkadziesiąt miliardów złotych, ${ }^{2}$ dokonując zakupu usług, dostaw czy robót budowlanych. Wysokość poniesionych wydatków przez instytucje publiczne w Europie to ponad 2 biliony euro, czyli 19\% PKB UE. ${ }^{3}$ Dla sektora publicznego stanowi to nie tylko konieczność rozsądnego wykorzystywania siły nabywczej, ale daje też szansę zakupu dóbr minimalizujących negatywny wpływ na środowisko, czyli takich, których oddziaływanie na środowisko w trakcie ich cyklu życia jest ograniczone w porównaniu do towarów, usługi robót budowlanych o identycznym przeznaczeniu, jakie zostałyby zamówione $\mathrm{w}$ innym przypadku. ${ }^{4}$ Popyt ze strony instytucji publicznych na „bardziej ekologiczne” towary kreuje i powiększa już istniejące rynki dla przyjaznych dla środowiska produktów i usług, a tym samym zachęca przedsiębiorstwa do rozwijania technologii środowiskowych

1 Podobnie M. Królikowska-Olczak, Zasada niedyskryminacji w prawie zamówień publicznych Unii Europejskiej, [w:] Ekonomiczne i prawne zagadnienia zamówień publicznych. Polska na tle Unii Europejskiej. Międzynarodowa konferencja naukowa 21-22 czerwca 2010 r. w Łodzi, A. Borowicz, M. Królikowska-Olczak, J. Sadowy, W. Starzyńska (red.), s. 9.

2 Dane statystyczne (wartości/ilości i rodzaju udzielonych zamówień) Biuletyn Informacyjny Urzędu Zamówień Publicznych nr 12/2012, s. 60, www.uzp.gov.pl, data publikacji: 17.12.2012 r.

3 Ekologiczne zakupy!, Podręcznik dotyczący zielonych zamówień publicznych, Wydanie II, Komisja Europejska, 2011, s. 5, dokument elektroniczny, http://ec.europa.eu/environment/gpp/pdf/handbook_pl.pdf (dostęp: 13.04.2013 r.).

4 Komunikat Komisji do Parlamentu Europejskiego, Rady, Europejskiego Komitetu Ekonomiczno-Społecznego oraz Komitetu Regionów, Zamówienia publiczne na rzecz poprawy stanu środowiska KOM (2008) 400 Bruksela, 16.07.2008 r., dokument elektroniczny, http://eurlex.europa.eu/LexUriServ/LexUriServ.do?uri= COM:2008:0400:FIN:PL:PDF (dostęp: 12.04.2013 r.). 
w tym zakresie, co z kolei przyczynia się do realizacji lokalnych, regionalnych, krajowych i międzynarodowych celów zrównoważonego rozwoju.

\section{Działania w zakresie wsparcia i promocji na rzecz zrównoważonej konsumpcji i produkcji na gruncie Unii Europejskiej}

Potencjał ekologicznych zamówień publicznych dostrzega się w ciągu ostatnich lat w coraz większym stopniu, ${ }^{5}$ choć jego znaczenie podkreślano już w komunikacie Komisji z 2003 r., ${ }^{6}$ w którym przyjęto Zintegrowana Politykę Produktowa Unii Europejskiej ukierunkowana na zmniejszenie zużycia zasobów i wpływu odpadów na środowisko. Komunikat nawiązywał do zrównoważonego rozwoju, jako części Procesu Lizbońskiego, ${ }^{7}$ a zasługuje na uwagę z tego powodu, iż dostrzeżono w nim po raz pierwszy wagę pojedynczych produktów dla całości procesu oddziaływań na środowisko. Podnoszono wówczas, iż efektywna polityka musi brać pod uwagę szereg cech produktów, które sprawiają, że są one obiektami rozpowszechnionymi dla podejmowanych działań ograniczających zanieczyszczenia, z uwagi na m.in. rosnącą ilość produktów, ich zróżnicowanie i funkcje, powstawanie produktów nowego rodzaju wskutek innowacji, a przede wszystkim na rosnący globalny obrót produktami.

W Komunikacie z 2004 r. ${ }^{8}$ podkreślając, iż zrównoważony rozwój wymaga rozwiązań globalnych, Komisja skupiła się na działaniach w zakresie stymulowania technologii w kierunku zrównoważonego rozwoju. Przyjęto wówczas Plan Działań dla Unii Europejskiej w zakresie technologii środowiskowych, którego celem było zaprzęgnięcie całego potencjału do ograniczenia presji na zasoby naturalne, poprawę jakości życia obywateli Europy, a przede wszystkim stymulowanie wzrostu gospodarczego. Komunikat miał istotne znaczenie, albowiem oparty był na założeniu, że istnieje dotąd niewykorzystany potencjał technologiczny, umożliwiający poprawę stanu środowiska przyczyniając się przy tym do konkurencyjności i wzrostu. W Komunikacie wskazano, iż czynniki decydujące, a wspomagające działania to m.in. przewidywalne przepisy prawne, trendy zachowań konsumenckich, a także

Szerzej zob., N. Miłostan, Zielone zamówienia publiczne jako przykład europeizacji publicznego prawa gospodarczego, [w:] Europeizacja publicznego prawa gospodarczego, H. Gronkiewicz-Waltz, J. Jaroszyński (red.), Warszawa 2011, s. 397 i n.

$6 \quad$ Komunikat Komisji dla Rady Parlamentu Europejskiego, Zintegrowana Polityka Produktowa. Wykorzystywanie podejścia środowiskowego opartego na analizie cyklu życia produktu, COM (2003)302, Bruksela, 18.06.2003 r., dokument elektroniczny, http://www.ekoportal.gov.pl/opencms/export/sites/default/ekoportal/dla_przedsiebiorcow_i_inwestorow/fundusze_unijne/Archiwum/GaleriaPlikow_FUE/Pliki_LIFE/20_Komunikat_ZPP.pdf, (dostęp: 10.04.2013 r.).

7 Wnioski Prezydium Rady Europejskiej w Göteborgu, 15-16 czerwca 2001 r., ustępy 19-32, dokument elektroniczny, http://ue.eu.int/pressData/en/ec/00200-r1.en1.pdf, (dostęp: 10.04.2013 r.).

8 Komunikat Komisji do Rady i Parlamentu Europejskiego, Stymulowanie technologii w kierunku zrównoważonego rozwoju: Plan Działań Unii Europejskiej w zakresie technologii środowiskowych, COM(2004)38 Bruksela, 28.01.2004 r., dokument elektroniczny, http://eurlex.europa.eu/LexUriServ/site/en/com/2004/com2004_0038 en01.pdf (dostęp: 10.04.2013 r.). 
sposób, w jaki władze kontrolujące wdrażanie prawa będą odnosić się do nowych technologii. Podnoszono również znaczenie wiarygodnej informacji gospodarczej i ekologicznej na temat technologii środowiskowych. Przyjęty Plan Działań identyfikował cztery obszary priorytetowe, tj. zmiany klimatu, przyrodę i różnorodność biologiczną, zdrowie i jakość życia oraz zarządzanie zasobami naturalnymi i odpadami.

Postulaty Komunikatu z 2004 r. przeniesiono zarówno do Dyrektywy 2004/17/ WE (dalej Dyrektywa sektorowa), ${ }^{9}$ jak i do Dyrektywy 2004/18/WE (dalej Dyrektywa klasyczna). ${ }^{10}$ Dyrektywy wyjaśniają, w jaki sposób instytucje zamawiające mogą przyczynić się do ochrony środowiska oraz promowania zrównoważonego rozwoju poprzez wskazanie możliwych do wykorzystania w tym celu środowiskowych kryteriów oceny ofert, systemów i środków zarządzania środowiskiem, a także ekoetykiet. ${ }^{11}$ Dyrektywy kładą nacisk na dążenie do uzyskania zamówień o najkorzystniejszej relacji jakości do ceny, przewidując możliwość uwzględniania kwestii środowiskowych w kolejnych fazach procedury udzielania zamówień publicznych, tj. na etapie opisu przedmiotu zamówienia, kwalifikacji wykonawców, wyboru najkorzystniejszej oferty, a wreszcie określania warunków realizacji umowy.

Kluczowe znaczenie dla polityki zielonych zamówień miały dwa Komunikaty Komisji 2008 r. ${ }^{12}$ i nie tylko z powodu druzgocącej krytyki podejmowanych działań lub ich zupełnego braku przez państwa członkowskie, ale z powodu ożywionej dyskusji w zakresie przyczyn tegoż stanu rzeczy i konieczności podejmowania środków zaradczych.

W pierwszym Komunikacie Komisja zarzuciła państwom członkowskim szereg niedociągnięć, stanowiących przeszkodę w pełnej realizacji zielonej polityki, począwszy od braku kompleksowych informacji, a na nieskoordynowanych, czy wręcz rozbieżnych działaniach na poziomie krajowym skończywszy. W efekcie czego producenci odbierali sprzeczne sygnały, co uniemożliwiało wykorzystanie pełnego potencjału rynku wewnętrznego, zwłaszcza iż wdrażanie polityki odbywało się niewystarczająco dynamiczne i perspektywiczne, mimo iż w 2005 r. opubliko-

9 Dyrektywa Parlamentu Europejskiego i Rady z dnia 31 marca 2004 r. koordynująca procedury udzielania zamówień przez podmioty działające w sektorach gospodarki wodnej, energetyki, transportu i usług pocztowych (Dz.U. L 134 z 30.4.2004, s. 1), www.uzp.gov.pl

10 Dyrektywa Parlamentu Europejskiego i Rady z dnia 31 marca 2004 r. w sprawie koordynacji procedur udzielania zamówień publicznych na roboty budowlane, dostawy, usługi (Dz.U. L 134 z 30.4.2004, s. 114), www.uzp.gov.pl

11 Oznakowanie ekologiczne Unii Europejskiej ustanowiono w 1992 r., aby zachęcić przedsiębiorstwa do wprowadzania do obrotu produktów i usług, które są bardziej przyjazne dla środowiska. W odniesieniu do ekoetykiet ustanowione są wymogi środowiskowe, które produkty lub usługi muszą spełnić, aby można je było opatrzyć takim oznakowaniem. Wymogi obejmują certyfikację produktu przez podmiot trzeci. Podstawą etykiet są informacje naukowe na temat wpływu produktu lub usługi na środowisko w ciągu całego cyklu życia, od pozyskania surowców, poprzez produkcję i dystrybucję, etap użytkowania po ostateczne unieszkodliwienie. Przy przyznawaniu tych etykiet stosuje się szereg kryteriów wyniku pozytywnego/negatywnego, które wyznaczają normę dla danego oznakowania. W odniesieniu do każdego produktu lub usługi objętych programem ustala się różne zbiory kryteriów. Ekologiczne zakupy!..., op. cit., s. 19.

12 Komunikat Komisji do Parlamentu Europejskiego, Rady, Europejskiego Komitetu Ekonomiczno-Społecznego oraz Komitetu Regionów, Plan działania na rzecz zrównoważonej konsumpcji i produkcji oraz zrównoważonej polityki przemysłowej KOM(2008)397, Bruksela 16.07.2008 r., dokument elektroniczny, http://eurlex.europa.eu/ LexUriServ/LexUriServ.do?uri=COM:2008:0397 
wany został przez Komisję podręcznik, ${ }^{13}$ który w sposób szczegółowy omawiał temat włączania aspektów środowiskowych do procedury zamówień publicznych oraz opisywał dotychczas zaobserwowane dobre praktyki w tej dziedzinie, m.in. kryteria ekologiczne zamówienia publicznego, czytanie ekoznaków oraz opracowane przez lokalne władze zasady ekologicznych zamówień w miastach europejskich.. ${ }^{14}$ W drugim Komunikacie uzasadniony niepokój Komisji budził fakt, iż na początku 2008 r. jedynie czternaście państw członkowskich w ogóle przyjęło krajowe plany działań. Jako główne przeszkody, utrudniające szersze korzystanie z Green Public Procurement (GPP) Komisja wskazała niewielką liczbę kryteriów środowiskowych dla produktów/usług, a mechanizmy upowszechniania tych, które istnieją jako niewystarczające. Komisja wskazała także na niedostateczne informacje na temat obliczania kosztu cyklu życia produktów oraz korzyści wynikających z przyjaznych dla środowiska produktów i usług. Niepokój Komisji budził fakt niepewności co do prawnych możliwości uwzględniania kryteriów środowiskowych w dokumentach przetargowych i brak wsparcia politycznego dla wdrażania/promowania GPP.

W marcu 2010 r. Komisja opublikowała Komunikat nt. Strategii na rzecz inteligentnego i zrównoważonego rozwoju sprzyjającego wtaczeniu społecznemu: Europa $2020,{ }^{15}$ którego celem jest wyjście Europy z kryzysu ekonomicznego i finansowego oraz przygotowanie jej gospodarki na kolejną dekadę. W Komunikacie zaznaczono, iż kształcenie i szkolenie odgrywają kluczową rolę dla inteligentnego, zrównoważonego i sprzyjającego włączeniu społecznemu rozwoju w kolejnej dekadzie. Jako priorytety wskazano rozwój gospodarki opartej na wiedzy i innowacji, efektywniej korzystającej z zasobów. Bardziej przyjaznej środowisku i bardziej konkurencyjnej, charakteryzującej się wysokim poziomem zatrudnienia i zapewniającej spójność gospodarczą, społeczną i terytorialną. Główne cele zaś to cel związany z edukacją, dotyczący problemu osób przedwcześnie kończących naukę szkolną, wzrost stopy zatrudnienia osób w wieku 20-64 lat, m.in. wskutek zwiększenia liczby pracujących kobiet i osób starszych oraz lepszej integracji migrantów na rynku pracy, a także zwiększenie inwestycji w działalność badawczo-rozwojową (B+R); ograniczenie emisji dwutlenku węgla oraz zwiększenie udziału odnawialnych źródeł energii w całkowitym zużyciu energii do 20\%; ograniczenie o 25\% liczby Europejczyków żyjących poniżej krajowej granicy ubóstwa, co będzie wymagać wydobycia z ubóstwa ponad $20 \mathrm{mln}$ osób.

13 Ekologiczne zakupy!, Podręcznik dotyczący zielonych zamówień publicznych, Komisja Europejska, Luksemburg Urząd Publikacji Unii Europejskiej, 2005 r., dokument elektroniczny, http://ec.europa.eu/environment/gpp/pdf/ buying_green_handbook_pl.pdf (dostęp: 12.04.2013 r.).

14 M. Charzyńska, Zielone zamówienia publiczne jako instrument wspierający zrównoważony rozwój na przykładzie regionu łódzkiego, [w:] Nowe podejście do zamówień publicznych - zamówienia publiczne jako instrument zwiększenia innowacyjności gospodarki i zrównoważonego rozwoju. Doświadczenia polskie i zagraniczne, J. Niczyporuk, J. Sadowy, M. Urbanek (red.), Warszawa 2011, s. 5. włączeniu społecznemu, KOM(2010) 2020, Bruksela 3.03.2010 r., dokument elektroniczny, http://ec.europa.eu / eu2020/pdf/1_PL_ACT_part1_v1.pdf (dostęp: 12.04.2013 r.). 
Zielone zamówienia publiczne, czyli polityka kreowania rynku zgodnego z zasadami...

\section{Działania w zakresie wsparcia i promocji na rzecz zrównoważonej konsumpcji i produkcji na gruncie krajowym}

Podstawowym aktem w Polsce, regulującym kwestie dotyczące udzielania zamówień publicznych jest ustawa Prawo zamówień publicznych (dalej ustawa Pzp). ${ }^{16}$ Ustawa w aktualnym brzmieniu odnosi się bezpośrednio do kwestii środowiskowych w kilku miejscach. Przepis art. 30 ust. 6 dopuszcza możliwość odstąpienia przez zamawiającego od opisu przedmiotu zamówienia za pośrednictwem polskich, europejskich lub międzynarodowych norm, jeśli zapewni on dokładny opis przedmiotu zamówienia poprzez wskazanie wymagań funkcjonalnych, obejmujących opis oddziaływania na środowisko. Przy czym specyfikacja oparta na wykonaniu/ funkcjonalności winna zawierać opis pożądanego rezultatu i oczekiwanych wyników pod względem jakości, ilości i rzetelności, w tym opis sposobu ich pomiaru. Nie może dotyczyć metod czy nakładów pracy. To potencjalni wykonawcy winni zaproponować optymalne, często innowacyjne rozwiązanie. ${ }^{17}$ Pewnym wsparciem w tym zakresie może być uregulowanie na gruncie prawodawstwa krajowego dialogu technicznego. ${ }^{18}$ Niewątpliwym plusem wprowadzenia nowego instrumentu oprócz możliwości efektywnego bezkosztowego wykorzystania systemu zamówień publicznych dla kreowania popytu m.in. na produkty innowacyjne o wysokiej, zaawansowanej technologii, ${ }^{19}$ jest także rozwianie niepewności „można - nie można” i jakie są tego skutki, bo przecież sama instytucja dialogu technicznego jest niczym nowym. Zarówno Dyrektywa klasyczna, ${ }^{20}$ jak i Dyrektywa sektorowa ${ }^{21}$ dopuszczały możliwość przeprowadzenia dialogu technicznego z zachowaniem zasady uczciwej konkurencji. Jednakże ramowy zapis powodował, iż zamawiający z tej możliwości korzystali rzadko lub w ogóle.

Kolejne przepisy, gdzie ustawa Pzp wprost odnosi się do kwestii środowiskowych, dotyczą kryteriów oceny ofert. Zgodnie z art. 91 ust. 2 ustawy Pzp: „kryteriami oceny ofert są cena albo cena $i$ inne kryteria odnoszące się do przedmiotu zamówienia, w szczególności jakość, funkcjonalność, parametry techniczne, zastosowanie najlepszych dostępnych technologii w zakresie oddziaływania na środowisko, koszty eksploatacji, serwis oraz termin wykonania zamówienia". ${ }^{22}$ Przy czym kryteria dotyczące zielonych zamówień publicznych obejmują nie tylko kryteria

\footnotetext{
Ustawa z dnia 29 stycznia 2004 r. Prawo zamówień publicznych (t.j. Dz.U. z 2010 r. Nr 113, poz. 759 ze zm.). Ekologiczne zakupy! Podręcznik..., op. cit., s. 38.

Ustawa z dnia 12 października 2012 r. o zmianie ustawy Prawo zamówień publicznych oraz ustawy o koncesji na roboty budowlane lub usługi (Dz.U. z 2012 r., poz. 1271).

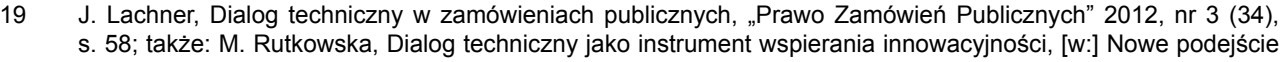
do..., op. cit., s. 105.

20 Motyw 8 Dyrektywy 2004/18/WE.

21 Motyw 15 Dyrektywy 2004/17/WE.

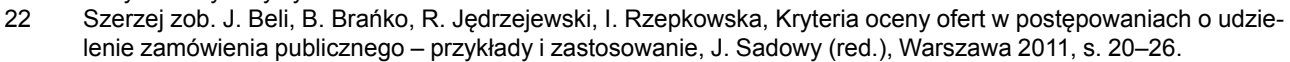


kwalifikacji i udzielenia zamówienia, ale również specyfikacje i klauzule dotyczące wykonania zamówienia. ${ }^{23}$

W celu wprowadzenia powyższych przepisów w życie oraz uwzględniając znaczenie ochrony środowiska, ustawodawca poszerzył katalog przestępstw skutkujących wykluczeniem z procedury przetargowej o przestępstwa przeciwko środowisku - art. 24 ust. 1 pkt 4-8. W myśl tych przepisów z postępowania o udzielenie zamówienia publicznego wyklucza się wykonawców, którzy albo których odpowiednio wspólnicy, partnerzy, członkowie zarządu, komplementariusze albo urzędujący członkowie organu zarządzającego zostali prawomocnie skazani za przestępstwo przeciwko środowisku. Ponadto przepisy wykonawcze ${ }^{24}$ wydane na podstawie art. 25 ust. 2 ustawy Pzp przewidują, że dla potwierdzenia, że oferowane dostawy, usługi lub roboty budowlane odpowiadają wymaganiom określonym przez zamawiającego, zamawiający może żądać, w szczególności zaświadczenia niezależnego podmiotu zajmującego się poświadczaniem zgodności działań wykonawcy z europejskimi normami zarządzania środowiskiem, jeżeli zamawiający wskazują środki zarządzania środowiskiem, które wykonawca będzie stosował podczas wykonywania zamówienia na roboty budowlane lub usługi, odwołując się do systemu zarządzania środowiskiem i audytu EMAS ${ }^{25}$ lub norm zarządzania środowiskiem opartych na europejskich lub międzynarodowych normach poświadczonych przez podmioty działające zgodnie z prawem Unii Europejskiej, europejskimi lub międzynarodowymi normami dotyczącymi certyfikacji.

Kluczową rolę w zakresie wsparcia i promocji polityki zrównoważonego rozwoju na gruncie krajowym odgrywają działania UZP. Urząd cyklicznie opracowuje i realizuje Krajowe Plany Działan ${ }^{26}$ w zakresie zielonych zamówień publicznych. Pierwszy Krajowy Plan Działań na lata 2007-2009 miał za zadanie głównie propagowanie zasad zrównoważonego rozwoju. W ramach Planu m.in. przetłumaczono na język polski oraz udostępniono na stronie internetowej UZP kryteria środowiskowe opracowane na zlecenie Komisji Europejskiej. Dla krajowych zamawiających stworzono podręcznik „Zielone zamówienia publiczne”, zawierający wytyczne w zakresie uwzględniania aspektów środowiskowych w procedurach przetargowych. Zorganizowano trzy krajowe konferencje, dotyczące zielonych zamówień publicznych, przeprowadzono dwie edycje szkoleń z GPP.

23 Podobnie S. Babiarz, Wybór najkorzystniejszej oferty, [w:] Prawo zamówień publicznych, Komentarz, S. Babiarz, Z. Czarnik, P. Janda, P. Pełczyński, Warszawa 2012, s. 432-433.

24 Rozporządzenie Prezesa Rady Ministrów z dnia 19 lutego 2013 r. w sprawie rodzajów dokumentów, jakich może żądać zamawiający od wykonawcy oraz form, w jakich te dokumenty mogą być składane (Dz.U. z 2013, poz. 231).

25 Eco-Management and Audit Scheme (EMAS) to system zarządzania środowiskowego, w którym dobrowolnie mogą uczestniczyć organizacje, przedsiębiorstwa, urzędy. Głównym założeniem systemu jest wyróżnienie tych organizacji, które wychodzą poza zakres minimalnej zgodności z przepisami i ciągle doskonalą efekty swojej działalności środowiskowej, www.emas-polska.pl/emas.html, dnia 13.04.2013 r. 
Zielone zamówienia publiczne, czyli polityka kreowania rynku zgodnego z zasadami...

Kolejny Krajowy Plan Działań, tj. na lata 2010-2012 miał za zadanie zwiększyć nie tylko stopień uwzględniania aspektów środowiskowych w zamówieniach publicznych, ale także społecznych. Jego analiza wskazała, iż aspekty środowiskowe w zamówieniach publicznych w roku 2012 osiągnęły poziom 12\%, zaś aspekty społeczne 2,90\%. ${ }^{27} \mathrm{~W}$ ramach Planu opracowano i wydano publikację ,Zielone zamówienia publiczne - II Podręcznik”, w którym m.in. poruszono zagadnienie rachunku kosztów cyklu życia oraz efektywności energetycznej w budownictwie oraz zaprezentowano nowy wzór etykiety energetycznej, której zasięg rozciągnięty został na produkty związane z energią, w tym drzwi i okna. Przetłumaczono na język polski i udostępniono na stronie internetowej UZP kolejne kryteria środowiskowe. Przetłumaczono na język polski wybrane orzeczenia Trybunału Sprawiedliwości Unii Europejskiej dot. zielonych zamówień publicznych. ${ }^{28} \mathrm{Na}$ stronie internetowej UZP utworzono zakładkę „Społeczne zamówienia publiczne”, w której zawarte zostały podstawowe informacje na temat aspektów prawnych regulujących kwestie społecznie odpowiedzialnych zamówień publicznych oraz dokumenty systematyzujące wiedzę w tym zakresie. Zrealizowano projekt „Lepsza przyszłość ekonomii społecznej”. W zakresie działalności informacyjno-szkoleniowej, zorganizowano trzy doroczne konferencje oraz przeprowadzono trzy edycje szkoleń.

Udostępniony obecnie na stronie internetowej UZP projekt Krajowego Planu Działań w zakresie zrównoważonych zamówień publicznych na lata 2013-2016 ${ }^{29}$ jako cele wskazuje dalszą popularyzację uwzględniania aspektów środowiskowych oraz społecznych w postępowaniach przetargowych. Do narzędzi, które mają pomóc $\mathrm{w}$ realizacji celów wybrano przede wszystkim szkolenia i upowszechnianie informacji o klauzulach społecznych. Do 2014 r. ma zostać stworzony nowy podręcznik dla zamawiających, w którym pojawią się konkretne przykłady zastosowania klauzul społecznych. Przedłożony projekt ma charakter operacyjno-wdrożeniowy, głównie w realizacji zintegrowanych strategii rozwoju, w tym Strategii Bezpieczeństwo Energetyczne i Środowisko - perspektywa do 2020 r., ${ }^{30}$ Strategii - Sprawne Państwo $2020,{ }^{31}$ Strategii Innowacyjności i Efektywności Gospodarki na lata 2012-2020 „Dynamiczna Polska”32 oraz Strategii Rozwoju Kapitału Społecznego. ${ }^{33}$

27 Urząd Zamówień Publicznych, Krajowy Plan Działań w zakresie zrównoważonych zamówień publicznych na lata 2013-2016, Warszawa 2012, s. 43 i 60.

28 Dotychczas przetłumaczono 4 orzeczenia, tj.: Orzeczenie z dnia 17 września 2002 r. w sprawie C 513/99 Concordia Bus; Orzeczenie z dnia 4 grudnia 2003 r. w sprawie C-448/01 Wienstrom GmbH; Orzeczenie z dnia 8 lipca 2010 r. w sprawie T 331/06 Evropaiki Dynamiki przeciwko EEA; Orzeczenie z dnia 10 maja 2012 r. w sprawie C-368/10 Komisja przeciwko Niderlandom, www.uzp.gov.pl

29 Dokument dostępny w zakładce „Zielone zamówienia publiczne”, www.uzp.gov.pl

30 Tryb dostępu: http://bip.mg.gov.pl/files/upload/16479/BEIS.pdf, data utworzenia: 12.07.2012 r.

31 Załącznik do uchwały nr 17 Rady Ministrów z dnia 12 lutego 2013 r. (poz. 136), dokument elektroniczny, http:// gamma.infor.pl/zalaczniki/mpo/2013/032/mpo.2013.032.136.0001.pdf, data ogłoszenia: 07.03.2013 r.

32 Dokument elektroniczny, http://www.mg.gov.pl/files/upload/17492/Strategia.pdf, (dostęp: 10.04.2013 r.).

33 Dokument elektroniczny, http://bip.mkidn.gov.pl/pages/polityka-wewnetrzna-i zagraniczna/strategia-rozwojukapitalu-spolecznego.php, (dostęp: 12.04.2013 r.). 


\section{Kryteria środowiskowe grup produktowych}

Kryteria środowiskowe dotyczące zielonych zamówień są rezultatem bliskiej współpracy służb Komisji, przedstawicieli przemysłu, społeczeństwa oraz państw członkowskich. Zostały opracowane dla tych grup produktowych, które uznano za najbardziej odpowiednie do wdrożenia GPP, zarówno ze względu na wartość zamówień, jak i wpływ na środowisko. Kryteria w odniesieniu do każdego sektora obejmują dwa poziomy, tj. kryteria podstawowe, w których uwzględniono najważniejsze rodzaje wpływu na środowisko, a które można zastosować przy ograniczonej do minimum konieczności dodatkowej weryfikacji lub przy minimalnym wzroście kosztów oraz kryteria kompleksowe, które mogą wymagać dodatkowej weryfikacji lub niewielkiego wzrostu kosztów w porównaniu z innymi produktami o takiej samej funkcjonalności.

Obecnie Komisja Europejska opracowała kryteria środowiskowe dla 18 grup produktowych, tj.: papier do kopiowania i papier graficzny, środki czyszczące i usługi sprzątania, biurowy sprzęt komputerowy, budownictwo, transport, meble, energia elektryczna, żywność i usługi cateringowe, wyroby włókiennicze, produkty i usługi ogrodnicze, okna, izolacja cieplna, płyty ścienne, skojarzona gospodarka energetyczna, oświetlenie uliczne i sygnalizacja świetlna, oświetlenie wewnętrzne, telefony komórkowe (wersja EN), twarde pokrycia podłogowe (wersja EN). ${ }^{34}$

Przykładowe kryteria środowiskowe dla wybranych grup produktowych, przy uwzględnieniu ich oddziaływania oraz podejścia zgodnego z zasadami GPP ${ }^{35}$ :

- papier do kopiowania i papier graficzny - negatywne oddziaływanie to przede wszystkim niszczenie lasów i potencjalna utrata różnorodności biologicznej, emisje zanieczyszczeń do powietrza i wody, zużycie energii oraz wytwarzanie odpadów podczas produkcji. Podejście zgodne z zasadami GPP to nabywanie papieru na bazie pokonsumpcyjnych włókien wtórnych lub papieru na bazie włókien pierwotnych pozyskanych w sposób legalny i/lub zrównoważony. W zakresie tego asortymentu proponuje się zestawy kryteriów w odniesieniu do papieru na bazie włókien wtórnych, papieru pochodzącego $\mathrm{z}$ recyklingu uwzględnione, w szczególności w ramach oznakowania „Błękitny anioł”, ${ }^{36}$ papieru na bazie włókien pierwotnych uwzględnione, w szczególności w ramach europejskiego oznakowania ekologicznego oraz oznakowania „Nordycki łabędź”,37

34

35

36

Kryteria środowiskowe - GPP dostępne w zakładce „Zielone zamówienia publiczne”, www.uzp.gov.pl

Opracowanie własne na podstawie: EU GPP Criteria - zestaw kryteriów środowiskowych Komisji Europejskiej, www.uzp.gov.pl

Błękitny Anioł (Der Blauer Engel), wprowadzony w 1977 r. z inicjatywy niemieckiego Ministerstwa Spraw Wewnętrznych. Jest najstarszą tego typu inicjatywą europejską. Obecnie certyfikacja znakiem "Der Blaue Engel" obejmuje 75 grup produktów i dotyczy około 4000 różnorodnych wyrobów, www.zielonezakupy.pl (dostęp: 14.03.2013 r.).

Nordycka Etykieta Ekologiczna przyznawana od 1989 r. przez Nordic Council of Ministers, czyli Stowarzyszenie Ministrów Krajów Skandynawskich: Szwecji, Finlandii, Norwegii i Islandii, a od 1997 r. i Danii. Znak ekologiczny 
Zielone zamówienia publiczne, czyli polityka kreowania rynku zgodnego z zasadami...

- środki czyszczące i usługi sprzątania - negatywne oddziaływanie to przede wszystkim zanieczyszczenie powietrza, tworzenie się smogu ozonowego, bioakumulacja $^{38}$ lub zagrożenie dla łańcucha pokarmowego i niebezpieczne oddziaływanie na organizmy wodne, a także negatywne oddziaływanie na zdrowie pracowników spowodowane stosowaniem niektórych środków czyszczących, zawierających rozpuszczalniki sklasyfikowane jako szkodliwe dla zdrowia oraz wytwarzanie odpadów opakowaniowych. Podejście zgodne z zasadami GPP to unikanie zbędnych produktów, unikanie niektórych substancji lub składników wchodzących w skład środków czyszczących, szkolenia personelu sprzątającego, zmniejszenie liczby wykorzystywanych opakowań, jak i zapewnienie zdolności poddania wykorzystywanych opakowań recyklingowi. W zakresie środków czystości proponuje się zestawy kryteriów w odniesieniu do przydatności do użycia, wymogów chemicznych, wymogów dotyczących opakowań, warunków realizacji zamówienia. W zakresie usług sprzątania proponuje się zestawy kryteriów w odniesieniu do stosowanych produktów, do personelu i organizacji przyjaznych dla środowiska technik sprzątania, a także warunków realizacji zamówienia;

- biurowy sprzęt komputerowy - negatywne oddziaływanie to przede wszystkim zużycie energii i związane z nim emisje dwutlenku węgla, zanieczyszczenie powietrza, gleby i wody, tworzenie się smogu ozonowego, bioakumulacja lub zagrożenie dla łańcucha żywnościowego i niebezpieczne oddziaływanie na organizmy wodne spowodowane niebezpiecznymi składnikami, np. zawartością rtęci w wyświetlaczach LCD i środkami zmniejszającymi palność, także negatywne oddziaływanie na zdrowie pracowników spowodowane hałasem oraz wytwarzanie odpadów, w tym opakowań, jak też ich ostateczne usuwanie. Podejście zgodne z zasadami GPP to zakup modeli energooszczędnych, zawierających ograniczoną ilość szkodliwych składników oraz propagowanie opcji zwrotu zużytych urządzeń. Zakup produktów o obniżonym poziomie emisji hałasu. Projektowanie z myślą o recyklingu oraz dłuższym okresie użytkowania, a także bezpieczne usuwanie produktów końcowych. W zakresie biurowego sprzętu komputerowego proponuje się zestawy kryteriów w odniesieniu do funkcji zarządzania energią, jakie posiada sprzęt, emisji hałasu, zastosowania rtęci w układzie przeciwoświetlenia monitorów LCD, demontażu sprzętu, zawartości materiałów wtórnych i możliwości ponownego ich przetworzenia, a także zastosowania w częściach z tworzyw sztucznych środków zmniejszających palność, okre-

łabędzia posiadają produkty przyjazne dla środowiska - zarówno na etapie produkcji, przez użytkowanie, kończąc na utylizacji, www.europapier.com (dostęp: 14.03.2013 r.). 
ślonych niektórymi zwrotami wskazującymi zagrożenie rakotwórcze, mutagenne lub szkodliwe dla rozrodczości;

- budownictwo - negatywne oddziaływanie to przede wszystkim zużycie energii do celów ogrzewania, chłodzenia, wentylacji, zaopatrzenia w ciepłą wodę i energię elektryczną oraz związaną z tym emisję $\mathrm{CO} 2$, zużycie zasobów naturalnych, w tym słodkiej wody - zarówno na etapie prac budowlanych, jak i podczas użytkowania. Emisje substancji szkodliwych dla zdrowia ludzkiego i dla środowiska podczas produkcji lub utylizacji materiałów budowlanych, prowadzące do zanieczyszczenia powietrza i wody. Podejście zgodne z zasadami GPP to optymalizacja charakterystyki energetycznej budynków, zapewnienie wysokich norm efektywności energetycznej w odniesieniu do instalacji grzewczej, chłodzącej, wentylacyjnej, zaopatrzenia w ciepłą wodę, a także urządzeń elektronicznych. Stosowanie umowy o efekt energetyczny z przedsiębiorstwami usług energetycznych. Wykorzystywanie zlokalizowanych odnawialnych źródeł energii (OZE) oraz wysokosprawnej kogeneracji. Systematyczne wprowadzenie koncepcji opartej na ocenie cyklu życia (LCA) w odniesieniu do materiałów budowlanych. Promowanie wykorzystywania pozyskanych i wyprodukowanych w sposób zrównoważony zasobów i materiałów budowlanych i izolacyjnych, także w oparciu o dostępność materiałów budowlanych na bazie surowców odnawialnych. Wykorzystywanie energooszczędnych pojazdów do transportu oraz na placu budowy, stosowanie efektywnych systemów zarządzania łańcuchem dostaw. Ograniczenie do minimum wytwarzania odpadów i prawidłowego nimi gospodarowania. W zakresie budownictwa proponuje się zestawy kryteriów w odniesieniu do wymogów w zakresie charakterystyki energetycznej, materiałów/wyrobów budowlanych, instalacji wodooszczędnych oraz kwalifikacji wykonawców;

- transport - negatywne oddziaływanie to przede wszystkim wpływ na zmianę klimatu poprzez emisję gazów cieplarnianych, wyczerpywanie zasobów, w szczególności paliw ze źródeł nieodnawialnych, zanieczyszczenie hałasem, wytwarzanie odpadów. Podejście zgodne z zasadami GPP to nabywanie pojazdów niskoemisyjnych. Mniejsze zużycie paliwa dzięki ekologicznemu sposobowi prowadzenia pojazdów, systemom monitorowania ciśnienia w oponach i sygnalizatorom zmiany biegów, przy jednoczesnym wykorzystaniu smarów o niskiej lepkości oraz opon o niskich oporach toczenia. W przypadku samochodów osobowych i pojazdów dostawczych proponuje się kryteria w odniesieniu do emisji CO2 i innych zanieczyszczeń, emisji hałasu, zużycia paliwa lub innych czynników oddziaływania pojazdów na środowisko. W zakresie pojazdów i usługi transportu publicznego proponuje się oprócz ww. kryteriów, kryteria w odniesieniu do szkoleń w zakresie ekologicznego sposobu prowadzenia pojazdów dla kierowców autobusów oraz wyposażenia dodatkowego służącego zmniejszeniu zużycia paliwa. W za- 
Zielone zamówienia publiczne, czyli polityka kreowania rynku zgodnego z zasadami...

kresie pojazdów do zbiórki odpadów i usługi w tym zakresie proponuje się wszystkie ww. kryteria łącznie.

\section{Podsumowanie}

Zielone zamówienia publiczne mogą stać się istotnym czynnikiem napędzającym innowacje na rynku, dostarczając sektorowi przemysłowemu realnych zachęt do tworzenia ekologicznych produktów i usług, szczególnie w branżach, w których nabywcy publiczni mają duży udział w rynku. Mogą również zapewnić organom publicznym oszczędności finansowe - szczególnie jeśli wziąć pod uwagę koszty zamówionych produktów lub usług w całym cyklu ich życia. I choć decyzja o udzieleniu zamówienia publicznego zgodnego z zasadami GPP w znacznej mierze ${ }^{39}$ jest uprawnieniem instytucji zamawiających, nie mniej jednak instytucje te winny mieć na uwadze, iż organy, które już realizują zielone zamówienia publiczne, będą lepiej przygotowane do sprostania zmieniającym się wyzwaniom $\mathrm{w}$ dziedzinie środowiska, jak również do osiągnięcia politycznych i wiążących celów w zakresie redukcji emisji CO2 i zwiększenia efektywności energetycznej oraz w innych dziedzinach polityki środowiskowej.

\section{BIBLIOGRAFIA}

Babiarz S., Wybór najkorzystniejszej oferty, [w:] S. Babiarz, Z. Czarnik, P. Janda, P. Pełczyński, Prawo zamówień publicznych, Komentarz, Warszawa 2012.

Beli J., Brańko B., Jędrzejewski R., Rzepkowska I., [w:] J. Sadowy (red.), Kryteria oceny ofert w postępowaniach o udzielenie zamówienia publicznego - przykłady i zastosowanie, Warszawa 2011.

Biuletyn Informacyjny Urzędu Zamówień Publicznych nr 12/2012.

Charzyńska M., Zielone zamówienia publiczne jako instrument wspierający zrównoważony rozwój na przykładzie regionu łódzkiego, [w:] J. Niczyporuk, J. Sadowy, M. Urbanek (red.), Nowe podejście do zamówień publicznych - zamówienia publiczne jako instrument zwiększenia in-

39 Z wyjątkiem: zakupu informatycznych urządzeń biurowych. Produkty te zakupione przez organy administracji centralnej muszą spełniać najnowsze minimalne wymogi w zakresie efektywności energetycznej, określone w rozporządzeniu w sprawie Energy Star, przy czym dotyczy to zamówień na dostawy, wycenianych jako przekraczające próg stosowania dyrektyw w sprawie zamówień publicznych - Rozporządzenie nr 106/2008 z dnia 15 stycznia 2008 r. w sprawie wspólnotowego programu znakowania efektywności energetycznej urządzeń biurowych (Dz. U. L 39/1 z 13.02.2008 r.); pojazdów transportu drogowego - wszystkie instytucje zamawiające muszą bowiem w procedurze udzielania zamówień uwzględniać czynniki energetyczne i oddziaływanie pojazdów na środowisko. Zapewniono wspólną metodykę obliczania kosztów operacyjnych w całym cyklu życia pojazdu - Dyrektywa 2009/33/WE z dnia 23 kwietnia 2009 r. w sprawie promowania ekologicznie czystych i energooszczędnych pojazdów transportu drogowego (Dz. U. L 120/5 z 15.05.2009); budynków - najpóźniej od 2013 r. we wszystkich nowych projektach budowlanych i w projektach ważniejszych renowacji będą musiały być stosowane wymagania minimalne dotyczące charakterystyki energetycznej. Od dnia 1 stycznia 2019 r. wszystkie nowe budynki zajmowane przez organy publiczne oraz będące ich własnością muszą być „budynkami o niemal zerowym zużyciu energii". Dyrektywa 2010/31/UE z dnia 19 maja 2010 r. w sprawie charakterystyki energetycznej budynków (Dz. U. L 153/13 z 18.6.2010 (wersja przekształcona). Ekologiczne zakupy! Podręcznik..., op. cit., s. 8. 
nowacyjności gospodarki i zrównoważonego rozwoju. Doświadczenia polskie i zagraniczne, Warszawa 2011.

Ekologiczne zakupy! Podręcznik dotyczący zielonych zamówień publicznych, Komisja Europejska, Luksemburg Urząd Publikacji Unii Europejskiej 2005.

Ekologiczne zakupy!, Podręcznik dotyczący zielonych zamówień publicznych, Wydanie II, Komisja Europejska, Luksemburg Urząd Publikacji Unii Europejskiej 2011.

Komunikat Komisji do Parlamentu Europejskiego, Rady, Europejskiego Komitetu Ekonomiczno-Społecznego oraz Komitetu Regionów, Zamówienia publiczne na rzecz poprawy stanu środowiska KOM (2008) 400, Bruksela, 16.07.2008 r.

Komunikat Komisji dla Rady i Parlamentu Europejskiego, Zintegrowana Polityka Produktowa. Wykorzystywanie podejścia środowiskowego opartego na analizie cyklu życia produktu, $\operatorname{COM}(2003) 302$, Bruksela, 18.06.2003 r.

Komunikat Komisji dla Rady i Parlamentu Europejskiego, Stymulowanie technologii w kierunku zrównoważonego rozwoju: Plan Działań Unii Europejskiej w zakresie technologii środowiskowych, $\operatorname{COM}(2004) 38$, Bruksela, 28.01.2004 r.

Komunikat Komisji do Parlamentu Europejskiego, Rady, Europejskiego Komitetu Ekonomiczno-Społecznego oraz Komitetu Regionów, Plan działania na rzecz zrównoważonej konsumpcji i produkcji oraz zrównoważonej polityki przemysłowe KOM(2008)397, Bruksela, 16.07.2008 r.

Komunikat Komisji do Parlamentu Europejskiego, Rady, Europejskiego Komitetu Ekonomiczno-Społecznego oraz Komitetu Regionów, Zamówienia publiczne na rzecz poprawy stanu środowiska, KOM (2008)400, Bruksela, 16.07.2008 r.

Komunikat Komisji, EUROPA 2020 Strategia na rzecz inteligentnego i zrównoważonego rozwoju sprzyjającego włączeniu społecznemu, $\operatorname{KOM}(2010)$ 2020, Bruksela, 3.03.2010 r.

Królikowska-Olczak M., Zasada niedyskryminacji w prawie zamówień publicznych Unii Europejskiej, [w:] A. Borowicz, M. Królikowska-Olczak, J. Sadowy, W. Starzyńska (red.), Ekonomiczne i prawne zagadnienia zamówień publicznych. Polska na tle Unii Europejskiej Międzynarodowa konferencja naukowa 21-22 czerwca 2010 r. w Łodzi, Warszawa 2010.

Lachner J., Dialog techniczny w zamówieniach publicznych, „Prawo Zamówień Publicznych” 2012, nr 3 (34).

Miłostan N., Zielone zamówienia publiczne jako przykład europeizacji publicznego prawa gospodarczego, [w:] H. Gronkiewicz-Waltz, J. Jaroszyński (red.), Europeizacja publicznego prawa gospodarczego, Warszawa 2011.

Rutkowska M., Dialog techniczny jako instrument wspierania innowacyjności, [w:] J. Niczyporuk, J. Sadowy, M. Urbanek (red.), Nowe podejście do zamówień publicznych - zamówienia publiczne jako instrument zwiększenia innowacyjności gospodarki i zrównoważonego rozwoju. Doświadczenia polskie i zagraniczne, Warszawa 2011.

Urząd Zamówień Publicznych, Krajowy Plan Działań w zakresie zrównoważonych zamówień publicznych na lata 2013-2016, Warszawa 2012.

Wnioski Prezydium Rady Europejskiej w Göteborgu, 15-16 czerwca 2001. 
It has become an important and crucial objective of European Union policy to award public procurement contracts for supply, services or construction works, which carry a guarantee that meeting the needs of the present generation will not compromise the needs of future generations. It concerns economic, social and environmental aspects of the strategic policy.

The subject of this study is to present measures taken to support and promote the policy for the benefit of sustainable consumption and production at both European Union (I) and domestic (II) level. The study describes in detail options of environmental criteria application in relation to selected product groups considering their interaction (III).

Keywords: promotion of green public procurement, sustainable development, policy strategy, National Action Plan, environmental criteria 